\title{
兵庫県淡路島北淡地方の力石
}

\author{
伊東 明* \\ （昭和42尔11月24日 受付）
}

\section{Chikara-ishi (Stone-lifting) in Awaji Isl., Hyōgo Prefecture}

\begin{abstract}
Alkira Ito (Sophia University,)
The weight-lifting game by using stone is played in the mountain areas in Switzerland and Spain. Also in Japan, it has been played among the people since the Edo era (1603 1867), and it was called "chikara-ishi".

Such chikara-ishi' is now found here and there ats hrines and temples in the northern part of Awaji Isl., in Hyōgo Prefecture. Those who did this stone-lifting were the young serf named "otoko-shi".

In summer, in the evenings, when their work was over, they gathered in a meeting place or a shrine or the ground of a temple in twos and threes and they competed for strength by lifting or practiced carrying stones. But as the change of social structure brought about a decline in the number of people of the "otoko-shi-class", labor became mechanized and the way of recreation was changed, and stonelifting has ceased to be played and only the reminiscence of the past are shown in monuments.

(Research Journal of Physical Education, Vol. 12, No. 4, 221 225,1968)
\end{abstract}

はじめに

淡路島の各地に力石が在ることは, 津名町在 住の田尾栄一氏の談話によつて知られていた。 今回調查したのは，汽路島北部の津名郡下の 津名町生穂部落, 長沢部落, 一宮町の多賀部落 の一部である.

$$
\begin{aligned}
& \text { 北淡路の力石の所在と状況 } \\
& \text { 津名町生穂 賀茂神社の力石 } \\
& \text { 力石の状沉 } \\
& \text { 切りつけ「奉上 賀茂力石」 } \\
& \text { 大きさ } 56 \mathrm{~cm} \times 43 \mathrm{~cm} \times 30 \mathrm{~cm} \\
& \text { 材質 黒みかげ石（金石） } \\
& \text { 形 状 小判型 }
\end{aligned}
$$

* :上智大学 体育学研究室

\section{力石の特長}

「切りつけ」に重量の表示がない。しかし， これを持ち上げた人びとは, 恐らくこの石が何 貫目あるかを知つていたのであろう。また「金 石」と称する黒みかげ石の力石は, 淡路島北部

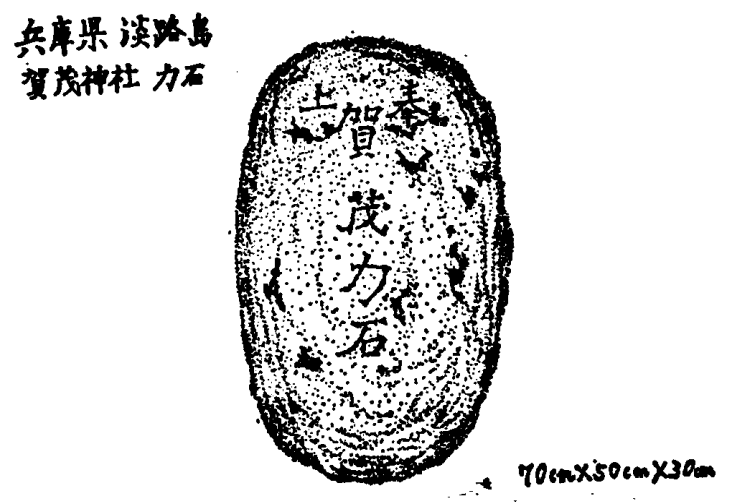


では珍らしい。

力持ちの行なわれた年代

賀茂神社宮司の書簡によれば，大正初期まで

は行なわれていたといら。

贺茂神社は，播磨薙に沼つた生穂部落の氏神 で，氏子中の力持ちが奉納したものであろう．

贺茂神社境内には 3 筒の力石があつたという

が，「賀茂力石」だけしか確諗できなかつた。

津名町長沢 金山比古神社の方石

力石の状況

金山比古神社の玉垣内，手洗石の横に，半分 ほど土に埋もれて，3 筒並べて谓かれている. 材質は全部，みかげ石である。

切门つけ 「三十メ」, 「三十三x」, 「四十メ」 大きさ $55 \mathrm{~cm} \times 40 \mathrm{~cm} \times 30 \mathrm{~cm}, 60 \mathrm{~cm} \times 45$ $\mathrm{cm} \times 35 \mathrm{~cm}, 70 \mathrm{~cm} \times 50 \mathrm{~cm} \times 40 \mathrm{~cm}$

形 状 即円型

力石の特長 重量の切りつけがあるだけで， 奉納, 年代, 人名ははいつていない，以前は数 筒あつたが，昭和40年の水害の際，神社の下の 道路の補修のために，3 䇫を除いて他の力石を 埋めてしまつたといら。

金山比古神社は，旧長沢村の氏神であり，䋈 礼の時には，若者達によつて相撲と力持ちが行 なわれた。

長沢部落の仲野氏の話によれば，力持ちは村 の青年達の間で，大正中期まで行なわれたとい כ.

津名町東山寺 平生山東山寺の力石

力石の状況

東山寺任門の脇に，刻字を上にして膡かれ ている。

初りつけ「奉上力石 三十四メ」

大きさ $55 \mathrm{~cm} \times 43 \mathrm{~cm} \times 30 \mathrm{~cm}$

材 質 金石（黒子がザ石）

形 状 角ばつた棈円型

東山寺主，佐伯秀明尼の馀話によれば，大正 初期には，境内にこのよ5な力石が 5 簓あつた が，現在では 1 筒しか残らていない。 津名町長沢 - 西下大師堂の力石
力石の状況

西下部落の大㸝堂の沓脱ぎ石として使われて いる。

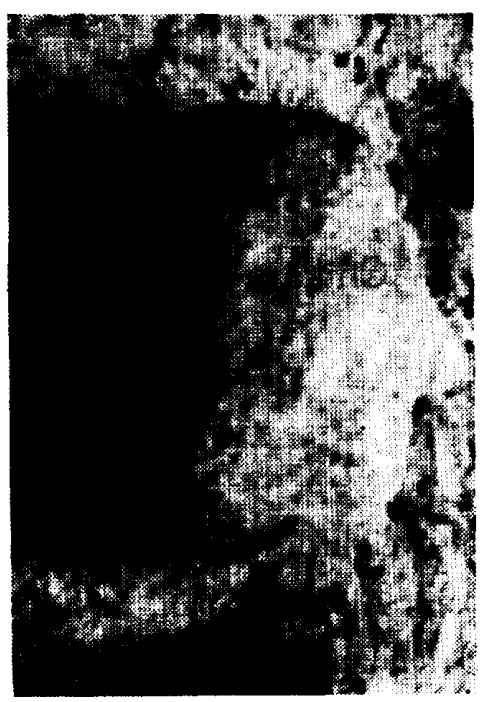

切りつけ「八十ょ」

大きさ $61 \mathrm{~cm} \times 49 \mathrm{~cm} \times 30 \mathrm{~cm}$

材 犋 金石（黑みかげ石）

型 状 小判型。

大師堂は部落の青年集会所となつて抒り，以 前には $2 \sim 3$ 䇠の稭古用の才石があつた。「八 十メ」石も稽古用のものであつて，沓脱ぎ石に 使われているため，刻字も磨減している。

一宮町多賀 伊梦諾神宮の力石

力石の状況

伊剕諾神宮境内の西門鳥居脇に 1 筬之，本殿 横の倉庫前に 1 箇放固されている.

1.「瀬岡」石

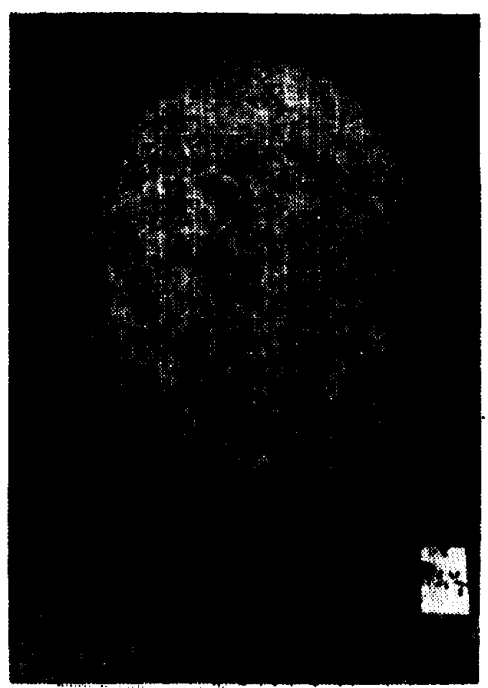


切りつけ「津名郡郡家村”瀬岡虎吉」

「昭和三年四月二十一日津名郡郡 家町 谷住竹松」

大きさ $70 \mathrm{~cm} \times 45 \mathrm{~cm} \times 35 \mathrm{~cm}$

材質みかげ石

形状 卵円型

‘瀬岡」石の特長

力石の典形的な形に整形してある。

正面の切りつけには「郡家村」となり，側面 のは「郡家町」となつて拔り，時日の経過を表 わしている。「奉上」「貫罒の切りつけはな W.

力石の持ら上げた人

切りつけにある「瀨風在占」は都家町の人で 伙罗諾神宮の氏子とだけで判明しない。

長昆書簡によれば，濑闭は，この力石を『肩 まで揚げるか揚げない程度で落したと公われて いる。』

「谷住竹松」は，郡家町北山に生まれ，大阪 第四師団问令部勤获中に師四の簐刀術競技会で 一等賞を獲得した。昭利 3 年 4 月 21 日，作壮諾 神宮例祭当日，境内に执いて，五十三三貫の力石 を局に担ぎあげ，その塨を数回まわつた。しか し，この後 1,2 年して腹膜炎に和かり，2,3 年 病附後，数点年 29 才で死亡した。位分すれば

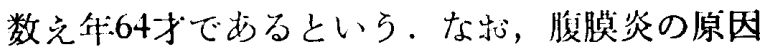
となつたのは，砈不担いだためであつたろう といわれている。

2. 練望用力石

划りつけなし

大きき $60 \mathrm{~cm} \times 40 \mathrm{~cm} \times 38 \mathrm{~cm}$

材質みかげ石

形 状 自然の互石

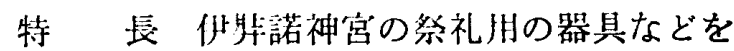
秋めてある會成の前の草むらに放崷され，タ一 ルで污れている，長昆蛹立の談話によれば，練 盗用の力石であつた，といわれている。

\section{北淡路の力石についての考察}

1. 力石の特長

北淡路の力石は, 神社や仏閣の境内に置かれ
てあるだけでなく，部落の青年会の集会所に， 稆習用の力石があることであろう，長沢部落の 仲野氏の談話によれば，このような力石は，大 正時代から昭和の初期までは，部落ごとに必ず 力石があつたといわれている.

練習用の力石は，青年会だけでなく，神社や 仏閣の境内にもあつた。通常，切りつけがない が，単に目方が刻んであるだけである。

正式の競技用の力石は，東山寺や賀茂神社の 力石に見られるように，「奉上」の刻字があり， 江戸などの力石に「奉納」と啀つてあるのと阔 じ意味であろう。

2. 力石の年代

北淡路の力石で年代が明確に版つてあるの は，伊葬諾神宮の「瀬岡石」だけである。その 他の力石には，年代を推定し得る奵りつけ，記 録は一つむなかつた。しかし，北淡路で力石に よる力持ちが行なわれた年代は，江戸時代の後 期から，大正年代の終わり頃までが最盛期であ つたようである。

3. 力石の形状

卵円形または恰山形のものが多く，力不とし ての典型的なものが多い，しかし，練留朋力石 では佲装諾神宮の力石のよらに，自然石の形の 整つたものを当てている.

大きさは, 長径 $55 \mathrm{~cm}$ から $70 \mathrm{~cm}$, 短径 $40 \mathrm{~cm}$ から $50 \mathrm{~cm}, 1 \%$ さ $30 \mathrm{~cm}$ から $40 \mathrm{~cm}$ のものが多 い.

4. 力石の材質

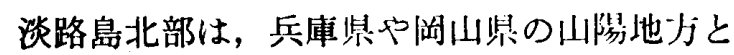
同じ花崗岩地質の地帯であるため，力石も，及 かげ石で作られたものが多い。

また，色の黒い，石質の繳密な「かな石」と 称する火山岩の力石むあるが，この「かな石」 は, 洲本，三原の淡路島南部で産する石である といら.

5. 力石で力持ちを行つた人びと

力石を报つた人びとは，農家の若者，とくに 「男衆」（抢とこし）と呼ばれた農家の下男階 級の青年達であつた。

北淡地方は海岸近くまで台地が張り出してい 
て平地が少ない，そのため，斜面は段々畑の水 田になつている所が多い，全ての農作業は，農 具にしても，肥料，収穫物にしても，まつ担い で畑まで上り下りしなければならない，むのを 担ぐための「力は，全ての労働の基礎となるる のであつた.」

事実, 男衆は, 玄米 8 斗入りの畚（ふこ）を 担いで家から田へ，あるいは街へ出ることは，

日常茶飯事であつたといわれている。

このような「力」を必要とする生活環境か ら，当然「力競べ「力持ち」が生れてきたの であろう。

中でも，いちばん「力」を必要としたのは， 力作業が生活の基盤となつていた階層, 即ち男 衆であった。男采は雇傭主である地主の家に部 屋を与えられ，農繁期には野良仕事ばかりでな く，夜が長くなると，夜なべ仕事までるさせら れた，冬になつて，全く農作業ができなくなる と，奋を担いで対岸の明石や，阪神地方へまで も出稼ぎに行く男衆も多かつた。そして，春と もなると，また淡路の地主の家へ㐎つてきて， もとの農作業に従事した。

6. 力石を持ち上げる方法

イ. 正式の持ち上げ方

両方の手を力石の長径の両端にかけて力石を 持ち上げ，かかえて胸まで挙げ，次いで局に担 <゙.

カがあり，また馴れている人は，胸のところ で休まないで担ぐが，力のない人や馿れていな い人は，一旦，胸のところで，ひと呼吸してか ら担ぐという。

口. 初心者の練望方法

重量の軽い力石から, 徐々に重い石に移つて 行くのは当然のことであつたろう．手散りのな い，丸い力石を持ら上げるのには，力だけでな く，熟練することが必要であり，初めて石を持 ち上げる者にとつては，非常に困難な技術であ つた.

そこで，繩を輪にして，力石の下に当て，再 手で輪になつた繩を持つて持ち上げる動作を繰 り返えし行ない，毠力を盖成すると同時に，力
石を胸まで上げるごつを憶えるようにした。 長沢部落の仲野氏は「初めての頃は, 繩を輪 にして，力石を持ち上げたものだ」と語つてい る。

7.「力持ち」を行なつた時期

力持ちを行なつた階層が，農作業の実際上の 担当者であつた男衆であつたことから，農作業 の労働内容と関係があつたろらとは，当然考え られる。

『農民や下級町人などの庶民階層にあつては， みずからの㓪みや賀しみの場を信仰祭儀に因ん だ年中行事などに求めた。しかも，それらは， 生産労働の䅂始に関係していることは注目に值 する（中略）こうした年中行事のなかに芸能や 相撲，力くらべなどの競技的なものが拈りこま れ想安㛝楽という意味ふかい一面が加わつてい た。これらは地方によつて若干の差異をみなが らバラェテイーにとみ実に多くのものが盛んに 招こなわれた。

しかし，元来は信仰的な社寺祭礼と結合した ものであつたし，さらにそれらは生産労働商業 と強い関連性をもち，ことに農耕作業の季節的 プロセスのケジメ＝節として設けられた意義あ るものであつた』（「德川時代からの大阪にみ るレクリエーションについて，桃山学院大学 三辺光夫）

北淡路の場合，「才持ち」の行なわれたのは， 八刀分夜, の日から8月1日, 所謂「八朔。 までの期間であつた。それは，八十八夜の頃に なると野良仕事が忙がしくなり，また夜が短か くなつて，今までやつていた佼業から解放さ れ，昼間の農作業だけになるからであり，八朔 になると，秋の夜長になつて夜業が課せられる ようになつて，夜遊びができなくなるからであ つた。

長い夏の日の夕刻，農作業から解放された男 臬たちは，三々伍々，部落の若者の集会所や社 寺の境内に集つて，力石を持ち上げて力競べを したり，新入りの者たちは力石を持ち上げる練 習に励んだ。男采の古参者や年長者が，年令の 若い男衆に，力石の持ち上げ方や担ぎ方を教え 
たのもここよらな時であつたろうし，長沢部 落の金山比古神社や大師堂の力石などはこのよ らな練疽や秿占の時に使われたものであつたろ 5 .

\section{8.「力持ち」の競技会}

淡路島では, 大正の末年頃まで部落, 村落か ら選ばれた地区代表の力持ちたちによつて，全 島的な力持ちの競技会が行なわれたというが， 部落内の力持ちの代表を決定する過程を除いて は，果して，このような大がかりな競技会が行 なわれたとかといら点に関しては，資料も記録 むなく不明な点が多い。

部落の力持占代表決定に際しては，平素の力 競べなどによつて，力持ちの格づけがなされて いたといらことであるが，交書に書いたるの， 即ち番附はなかつたといら. 若し, 番附が発見 されたならば，力持ちの解明のための貴重な資 料となることであろう。

9. 力石による力持ちの哀退の要因 力持ちの衰䃍の原因としては種々の要因があつ たろらが，主なものとして，次の 3 つが挙げら れるであろう。

イ. 淡路の農業形態の变化

明治維新による封建制度の崩㙞により，農奴 的な男衆といら下男制度がなくなたつこと，特 に戦後は，農地開放による地主階級の没落は， 農業の自家経営が本すじとなつて, 男衆は存在 しなくなつた。そんため，力持ちの競技は，そ の担い手を失つてしまつた。

\section{口. 農作業の機械化}

農作業だけに止まらず，運搬その他の労働作
業の機械化, 動力使用は, 単純な力を必要とす る作業を駆逐してしまつた。

八. 農村娛楽の変化

交通機関，放送網の発達は，僅かの時間で娱 楽を求めることができ，部落内だけの閉鎖的 な，素朴な青年会の集会や生活に直結した泥く さい力競へ，力持ちのような競技は顧みられな くなつた。

10. 北淡路に怙ける力不の保存状況

北淡路の各地に存在する力石は消減寸前にあ るといってよい。

材質が，堅牢な石であるがために風化を货か れ，重量があるために移転，運搬，盗難をまぬ かれて，神社，仏閣の境内に放置されながら も，ひつそりと存在を許されている。

住民の間でも，力持らが話題になることもな く，力石に関心を払うこともなく，力石の何で あるかといらことも全く知らない。

江戸時代から，庶民に親しまれ，汗みどろに なつて若者たちが取り組み，挑んだ力石は，や はり，封建時代の下積みの若者たちの記念碑と してでも保存の手段を講じるべきであろう。

\section{参考文嗝}

児玉幸多「近世農民结活史」(新稿版) 吉川弘文館 绝39年7月，P168. P177.P342.

津名郡神社稳代会「津名郡神社鿁」

津名郡神社総代会 昭和39年9月

三辺光夫「徳川時代からの大这にみるレクリエー ションについて」狛利40年 